\title{
IMPLEMENTASI SIKAP PEDULI SOSIAL PADA MASYARAKAT DUSUN BUMI PERMAI KECAMATAN LABUAPI KABUPATEN LOMBOK BARAT
}

\author{
Tanti Rizkian Sari, Dahlan ${ }^{2}$, Muh. Mabrur Haslan ${ }^{3}$ \\ ${ }^{1}$ Mahasiswa Prodi PPKn, ${ }^{23}$ Dosen Jurusan Pendidikan IPS \\ Fakultas Keguruan dan Ilmu Pendidikan Universitas Mataram \\ Email: dahlan.01fkipgmail.com
}

\begin{abstract}
ABSTRAK
Penelitian ini bertujuan untuk mendeskripsikan: (1) bentuksikap peduli sosial pada masyarakat Dusun Bumi Permai, (2) implementasi sikap peduli sosial pada masyarakat di Dusun Bumi Permai, dan (3) faktor penghambat implementasi sikap peduli sosial pada masyarakat di Dusun Bumi Permai. Penelitian ini menggunakan pendekatan penelitian kualitatif dengan metode deskriptif. Temuan dalam penelian yaitu: (1) bentuk sikap peduli sosial pada masyarakat di Dusun Bumi Permai, antara lain, tolong menolong, bekerjasama, toleransi dan empati. 2) impelementasi tolong menolong, antara lain: menolong tetangga yang sakit, menjadi relawan, membagikan makanan untuk buka puasa. 3) implementasi toleransi, antara lain: tidak mengganggu ibadah agama lain, komunikasi menggunakan bahasa nasional, ikut merayakan hari raya agama Islam, menghargai perbedaan pendapat, menghargai perbedaan kepentingan. 4) implementasi kerjasama, antara lain: gotong royong, pembentukan dan pembubaran panitia. 5) empati. 6) faktor penghambat implementasi sikap peduli sosial, antara lain: kurangnya motivasi, keluarga, lingkungan, media elektronik, waktu dan kesempatan.
\end{abstract}

Kata Kunci: Sikap, Peduli Sosial

\begin{abstract}
This study aims to describe: (1) the form of social caring attitudes in the community of Bumi Permai Hamlet, (2) the implementation of social care for the people in Bumi Permai Hamlet, and (3) the inhibiting factors for the implementation of social caring attitudes in Bumi Permai Hamlet. This study uses a qualitative research approach with descriptive methods. The findings in the study are: (1) the form of social care for the people in Bumi Permai Hamlet, among others, help, cooperation, tolerance and empathy. 2) implementation of help, including: helping sick neighbors, volunteering, distributing food for breaking fast. 3) implementation of tolerance, among others: not disturbing the worship of other religions, communication using naional languages, participating in celebrating Islamic holidays, respecting differences of opinion, respecting differences in interests. 4) implementation of cooperation, among others: mutual cooperation, formation and dissolution of the committee. 5) empahy. 6) inhibiting factors for implementing social caring attitudes, among others: lack of motivation, family, environment, electronic media, time and opport unity.
\end{abstract}

Keywords: Attitude, Social Care 
Vol. 6 No. 1, Oktober-Maret 2019, hh. 67-76

\section{PENDAHULUAN}

Indonesia merupakan bangsa yang majemuk dengan keanekaragaman, baik dalam bidang suku dan ras, adat istiadat, kebudayaan, agama, serta perbedaan kedaerahan. Menurut Nisa (2017: 5), terdapat lebih kurang 500 suku bangsa yang terdapat di Indonesia. Keseluruhan dari suku bangsa itu tersebar luas diseluruh wilayah nusantara. Jumlah ini belum termasuk dalam sub suku yang beragam dengan menggunakan bahasa, adat istiadat dan kebiasaan yang berlainan pula.

Keberagaman suku, ras, agama, pekerjaan, jenis kelamin, dan warna kulit tersebut bukan menjadi hal yang perlu dipertentangkan di lingkungan bermasyarakat, berbangsa dan bernegara. Keberagaman tersebut mendominasi masyarakat sehingga terjalin sebuah interaksi dalam kehidupan sehari-hari. Agar dapat hidup dengan baik dan memenuhi kodratnya sebagai makhluk sosial, mereka melakukan aktivitas interaksi baik itu antar perorangan, perorangan dengan kelompok, sesama agama, maupun etnis.

Dalam menjalani kehidupan sehari-hari, perlu suatu perasaan bersedia menolong orang lain, baik itu tetangga, teman, keluarga, dan semua warga masyarakat, dikarenakan hal tersebut dapat meringankan beban atau mengurangi penderitaan dari orang lain. Terjalinnya berbagai bentuk hubungan antar anggota masyarakat dapat mengembangkan sikap peduli sosial yang tertanam dalam diri masing-masing individu anggota masyarakat.

Peduli menurut Nisa (2017:35), berarti memerhatikan atau menghiraukan sesuatu, peduli sosial yang di maksud bukan untuk mencampuri urusan orang lain, tetapi lebih pada membantu menyelesaikan permasalahan yang dihadapi orang lain dengan tujuan kebaikan dan perdamaian.

Pentingnya sikap peduli sosial antar masyarakat sangat dibutuhkan, misalnya sebagai wujud toleransi antar sesama, saling mengerti penderitaan satu sama lain, dan bentuk pengertian akan kesusahan yang sedang dialami seseorang. Kerukunan dan kebersamaan dalam masyarakat dapat ditingkatkan, sehingga akan menciptakan keharmonisan dalam berbagai lapisan masyarakat.

Bertumpu pada pemaparan di atas, Dusun Bumi Permai yang berada di desa Telagawaru, Kecamatan Labuapi, Kabupaten Lombok Barat, sangat menarik untuk dikaji mengenai implementasi sikap peduli sosial pada masyarakat di dalamnya.

Berdasarkan studi pendahuluan yang telah dilakukan oleh peneliti, Dusun Bumi Permai, memiliki komposisi masyarakat sangat beragam, bahkan menjadi tujuan utama para pendatang untuk bermukim karena berada di daerah yang cukup strategis, yaitu berada dipinggir kota Mataram dan diapit oleh desa-desa yang asri dan maju. Perbedaan suku, adat istiadat, bahasa, warna kulit, pekerjaan, dan agama sudah menjadi fenomena setiap harinya dalam kehidupan bermasyarakat di daerah tersebut.

Namun masyarakat yang berada di dalam dusun ini memiliki masalah sosial yang bervariasi, salah satunya adalah gotong royong. Masyarakat cenderung kurang aktif mengikuti kegiatan-kegiatan yang diadakan di dusun tersebut, khususnya yang berekonomi tinggi jarang sekali untuk berinteraksi dengan tetangga, bahkan sampai ada yang tidak kenal satu sama lain. Kurangnya sikap peduli sosial juga dipengaruhi 
berbagai persoalan, mulai dari kurangnya interaksi yang dilakukan masyarakat, status sosial, kedudukan dan kekayaan (wawancara, Widjohan: 2 Agustus 2017).

Berdasarkan uraian latar belakang diatas, maka dapat dirumuskan permasalahan dalam peneltian ini adalah: 1) apa bentuk sikap peduli sosial pada masyarakat Dusun Bumi Permai?;2) bagaimana implementasi sikap peduli sosial pada masyarakat Dusun Bumi Permai?; 3) apa faktor penghambat dalam mengimplementasikan sikap peduli sosial pada masyarakat Dusun Bumi Permai? Kemudian dari rumusan masalah tersebut maka dapat diketahui tujuan dari penelitian ini adalah: 1) Untuk mengetahui bentuk sikap peduli sosial pada masyarakat Dusun Bumi Permai;2) Untuk mengetahui implementasi sikap peduli sosial pada masyarakat Dusun Bumi Permai; dan3) untuk mengetahui faktor penghambat dalam mengimplementasikan sikap peduli sosial pada masyarakat Dusun Bumi Permai.

\section{METODE PENELITIAN}

Penelitian ini menggunakan penedekatan kualitatif dengan metode deskriptif, karena penelitian ini akan mendeskripsikan atau menggambarkan secara mendalam tentang bentuk sikap peduli sosial pada masyarakat Dusun Bumi Permai, implementasi sikap peduli sosial pada masyarakat Dusun Bumi Permai dan faktor penghambat dalam mengimplementasikan sikap peduli sosial pada masyarakat Dusun Bumi Permai.Tempat penelitian ini dilakukan di Dusun Bumi Permai, Kecamatan Labuapi, Kabupaten Lombok Barat. Penelitian ini telah dilaksanakan mulai bulan Mei sampai Juli Tahun 2018.

Subyek dalam penelitian ini adalah masyarakat yang berdomisili di Dusun Bumi Permai. Subyek peneltian ditentukan dengan menggunakan snowball sampling, teknik penentuan sampel sumber data yang pada awalnya berjumlah sedikit, lama-lama menjadi besar. Hal ini dilakukan karena dari jumlah sumber data yang sedikit tersebut belum mampu memberikan data yang memuaskan, sehingga mencari orang lain lagi yang dapat digunakan sebagai sumber data. Dengan demikian, jumlah sampel sumber data akan semakin besar seperti bola salju yang menggelinding, lama-lama menjadi besar.

Informan dalam penelitian ini adalah Kepala Dusun Bumi Permai, Ketua RT 1, Ketua RT 2, Ketua RT 3 , Ketua RT 4, dan Ketua RT 5A. Informan ditentukan menggunakan purposive sampling, dengan pertimbangan orang tersebut dianggap paling tahu tentang apa yang kita harapkan atau mungkin dia sebagai penguasa sehingga memudahkan peneliti menjelajah objek/situasi social yang diteliti.

\section{HASIL PENELITIAN}

\section{Bentuk Sikap Peduli Sosial Pada Masyarakat Dusun Bumi Permai, Kecamatan Labuapi, Lombok}

\section{Barat}

\section{Kerjasama.}

Berdasarkan hasil wawancara dengan subyek dan informan penelitian menunjukkan bahwa masyarakat Dusun Bumi Permai menunjukkan bentuk sikap peduli sosial bekerjasama. Seperti yang dituturkan oleh subyek SZ bahwa: "ya, kita bisa dibilang peduli terhadap sesama. Bentuknya beragam, 
Vol. 6 No. 1, Oktober-Maret 2019, hh. 67-76

seperti tadi menolong tetangga, bekerjasama, empati juga. Empati ini kan awal mulanya, tumbuh dari hati kemudian setelah itu baru kita aksi”(wawancara: 3 Juni 2018). Sementara itu, informan LJ menuturkan bahwa: "saya sebernarnya merasa cukup bangga dengan warga di sini, sebab kepedulian mereka cukup membantu masyarakat yang membutuhkan. Tapi adek bilang bentuk pedulinya seperti kerjasama, tolong menolong, empati, toleransi, ya itu memang betul sudah dijalankan oleh warga di sini” (wawancara, 1 Juli 2018).

\section{Tolong menolong}

Berdasarkan hasil wawancara dengan subyek dan informan penelitian menunjukkan bahwa masyarakat Dusun Bumi Permai menunjukkan bentuk sikap peduli sosial tolong menolong. Seperti yang dituturkan oleh subjek SH bahwa: "iya kita tolong lah jika ada kerabat atau tetangga yang meminta bantuan. Kalau bentuknya bisa materi dan non materi”" (wawancara: 2 Juni 2018). Sementara itu informan KW, menurutkan: "apabila kita membahas peduli sosial, maka bentuknya beragam, dari kami sendiri misalkan dalam pembangunan masjid, saya non muslim tapi sering ikut ibu-ibu lainnya ketika masak untuk bapak-bapak yang bekerja di masjid. Kemudian waktu gempa kermarin, kami urunan untuk membantu korban bencana di Kabupaten Lombok Utara. Saya rasa masyarakat di sini cukup peduli dengan sesama. Kemudian kita sangat sedih terhadap korban gempa tersebut, semoga kita semua diberi kekuatan. Kalo dari segi bahasa, karena kita kan dari daerah yang beragam, jadi ya kita pake bahasa Indonesia kalau berkomunikasi, biar semuanya ngerti gitu, tidak ada yang tersinggung"(wawancara, 28 Juni 2018).

\section{Toleransi}

Berdasarkan hasil wawancara dengan subyek dan informan penelitian menunjukkan bahwa masyarakat Dusun Bumi Permai menunjukkan bentuk sikap peduli sosial toleransi. Subjek EA menuturkan bahwa: "dalam hal peduli sosial, kami mungkin bisa mengilustrasikan seperti ini, misalkan kami muslim kemudian ada tetangga kita yang nonmuslim sedang mengadakan acara keagamaan di sini, kami turut membantu dalam menertibkan parkiran, kemudian membantu menata ruangan dan sebagainya. Kemudian bagi yang non muslim, mereka memperlihatkan bahwa toleransi di sini sangat kuat pada saat bulan puasa berlangsung. Mereka sangat sungkan untuk makan di luar, bahkan ada yang ikut puasa"(wawancara: 3 Juni 2018). Sementara itu, subjek LW mengatakan bahwa: mengatakan bahwa: "bentuk sikap peduli sosial pada masyarakat di dusun Bumi Permai memang beragam, dalam aspek toleransi. Masyarakat memiliki toleransi yang cukup baik. Antar agama mereka sagat rukun. Yang muslim bertoleransi kepada tetangganya yang nonmuslim, sebaliknya juga begitu. Kemudian dari adat dan kebiasaan, walaupun adat setiap masyarakat berbeda karena asalnya juga berbeda, tapi masyarakat lain menerima. Malah masyarakat di sini menggunakan bahasa Indonesia. Sebagai bentuk toleransi dan persatuan (wawancara, 25 Juni 2018). 


\section{Empati}

Berdasarkan hasil wawancara dengan subyek dan informan penelitian menunjukkan bahwa masyarakat Dusun Bumi Permai menunjukkan bentuk sikap peduli sosial empati. Hal ini dituturkan oleh subjek SZ bahwa: "iya, kita bisa dibilang peduli terhadap sesama. Bentuknya beragam, seperti tadi menolong tetangga, bekerjasama, empati juga. Empati ini kan awal mulanya, tumbuh dari hati kemudian setelah itu baru kita aksi”(wawancara: 3 Juni 2018). Sementara itu, informan LW menuturkan bahwa: "empati, karena ini hanya hati nurani yang mengetahui, tapi saya yakin semua warga pasti sedih dan perihatin, ikut merasakan apa yang dirasakan oleh warga lainnya apabila mengalami musibah" (wawancara, 25 Juni 2018).

\section{Implementasi sikap peduli sosial pada masyarakat Dusun Bumi Permai Kecamatan Labuapi}

\section{Kabupaten Lombok Barat}

1. Kerjasama, yang dilakukan melalui kegiatan-kegiatan seperti:

a. Bergotong royong, yakni membangun masjid Baitul Qadri dimulai dari tahun 2014 hingga sekarang. Kegiatanini rutin dilaksanakan setiap hari minggu mulai pukul 06.00 hingga 11.00 siang.

b. Membantu hajatan, dimana warga di sini memberikan bantuan berupa materi (uang), juga para ibu-ibu akan membantu memasak untuk dihidangkan selama 2 hari berturut-turut, kemudian kaum pria akan bertanggungjawab pada perlengkapan dan sebagainya.

2. Tolong menolong. Adapun tolong menolong dilakukan melalui kegiatan, sebagai berikut:

a. Membantu tetangga yang kesusahan, dimana ketika ada kerabat atau tetangga yang sakit, maka yang terlebih dahulu menolong untuk dibawa ke rumah sakit adalah warga setempat.

b. Turut aktif menjadi relawan, dimana ketika Lombok mengalami musibah gempa bumi pada bulan Agustus 2018, warga di Dusunini saling membahu menolong korban bencana di lokasi pusat gempa KLU. Kemudian beberapa warga di sini menjadi relawan di lapas untuk memberikan siraman rohani kepada para narapidana tanpa dibayar oleh siapapun.

3. Toleransi (menghargai orang lain). Adapun toleransi dapat dilihat melalui kegiatan-kegiatan, sebagai berikut:

a. Tidak mengganggu tetangga yang sedang beribadah

b. Turut mengantarkan makanan pada saat bulan puasa

c. Menggunakan bahasa Indonesia sebagai bahasa sehari-hari

d. Empati. Hal ini karena kegiatan-kegiatan yang dilakukan oleh masyarakat dilandasi oleh rasa empati.

Faktor penghambat dalam mengimplementasikan sikap peduli sosial pada masyarakat Dusun Bumi Permai, Kecamatan Labuapi, Kabupaten Lombok Barat.

Berdasarkan hasil wawancara subjek penelitian di atas, dapat dijelaskan bahwa faktor penghambat dalam menerapkan sikap peduli sosial pada masyarakat dusun Bumi Permai, yakni intern dan ekstern. 
Vol. 6 No. 1, Oktober-Maret 2019, hh. 67-76

Adapun faktor intern adalah kurangnya motivasi. Masyarakat memiliki motivasi atau minat yang rendah untuk peduli terhadap sesama sehingga akan menghambat impelementasi sikap peduli sosial. Faktor ekstern terdiri dari: Keluarga, Lingkungan, media elektronik. waktu dan kesempatan. Dalam penelitian ini, peneliti mendapatkan temuan bahwa waktu dan kesempatan merupakan salah satu faktor penghambat implementasi sikap peduli sosial pada masyarakat.

\section{PEMBAHASAN}

Bentuk Sikap Peduli Sosial pada Masyarakat Dusun Bumi Permai Kecamatan Labuapi, Kabupaten

\section{Lombok Barat}

\section{Tolong Menolong}

Bentuk tolong menolong yang dapat dilakukan oleh masyarakat Dusun Bumi, digolongkan menjadi 2, yakni berupa materi dan nonmateri.

\section{Toleransi}

Dari hasil penelitian menunjukkan bahwa, masyarakat sudah menjunjung tinggi toleransi. Toleransi memunculkan identitas ganda yang bersifat hirarkis, artinya seseorang tidak akan melepas identitas asalnya dan memiliki suatu identitas bersama yang lebih tinggi nilainya, contoh masyarakat Dusun Bumi Permai berasal dari Minang, Batak, Bali, Cina, Sumbawa, Bima, dan Jawa, namun mereka memiliki suatu kesatuan bersama yang lebih diutamakan yaitu sebagai rakyat Indonesia.

\section{Kerjasama}

Warga di Dusun Bumi Permai menunjukkan adanya aktivitas kerjasama untuk saling membantu dan meringankan beban orang lain.

\section{Empati}

Empati merupakan landasan awal terjadinya kepedulian sosial. Empati dimiliki oleh setiap warga di Dusun Bumi Permai, merasakan apa yang dirasakan oleh orang lain yang terkena musibah, atau sedang bahagia. Hasil penelitian menunjukkan bahwa seluruh objek maupun informan selalu memiliki rasa empati ketika melihat orang lain sedang terkena musibah walaupun tidak membantu berupa tindakan.

Implementasi sikap peduli sosial pada masyarakat Dusun Bumi Permai, Kecamatan Labuapi, Kabupaten Lombok Barat

1. Tolong Menolong, diimplementasikan melalui kegiatan-kegiatan sebegai berikut:

a. Menolong tetangga yang sakit

b. Menjadi relawan (orang yang rela memberikan bantuan tenaga maupun materi tanpa meminta imbalan)

1) Volunter Lapas

2) Anggota Majelis Ta'lim 
c. Membagikan makanan untuk buka puasa

2. Toleransi, diimplementasikan melalui kegiatan-kegiatan sebegai berikut:
a. Tidak mengganggu ibadah agama lain
b. Komunikasi menggunakan bahasa nasional
c. Ikut merayakan hari besar agam Islam
d. Menghargai perbedaan pendapat
e. Menghargai perbedaan kepentingan

3. Kerjasama, dapat terlihat dari beberapa aktivitas berikut ini, antara lain:

a. Gotong royong

1) Gotong royong pembangunan masjid

2) Gotong royong memasak dalam acara yang diadakan

b. Pembentukan dan pembubaran panitia acara

4. Empati

Hasil penelitian menunjukkan bahwa seluruh objek maupun informan selalu memiliki rasa empati ketika melihat orang lain sedang terkena musibah walaupun tidak membantu berupa tindakan. Implementasi empati ini akan berakhir apabila warga yanng terkena musibah tersebut telah membaik.

Faktor penghambat dalam mengimplementasikan sikap peduli sosial pada masyarakat Dusun Bumi Permai, Kecamatan Labuapi, Kabupaten Lombok Barat

\section{Faktor Intern}

Berdasarkan hasil penelitian, dapat ditunjukkan bahwa masyarakat di Dusun Bumi Permai memiliki motivasi yang kurang dalam mengimplementasikan sikap peduli sosial. Dalam setiap kegiatan yang diadakan di dusun tersebut, warga harus diminta berulang kali untuk turut berpartisipasi. Bahkan untuk beberapa acara seperti tahlilan, pengajian, yasinan, gotong royong dan arisan maksimal hanya 30 orang saja yang hadir dari keseluruhan warga di dusun tersebut.

\section{Faktor ekstern}

\section{a. Faktor keluarga}

Keluarga yang tidak atau kurang mendukung anggotanya untuk mengikuti kegiatan-kegiatan yang diadakan, maka akan menghambat orang tersebut mengimplementasikan sikap peduli sosial. Seperti pada kegiatan untuk bergotong royong, rapat RT, pembentukan dan pembubaran panitia, memasak bersama, banyak kaum ibu-ibu tidak dibolehkan oleh suaminya untuk mengikuti kegiatan tersebut karena harus meninggalkan rumah dalam waktu yang cukup lama. Begitu pula dengan lakilaki yang bergotong royong di masjid. Banyak laki-laki yang tidak mengikuti kegiatan gotong royong karena akan menghabiskan waktu bersama keluarga di rumah. 
Vol. 6 No. 1, Oktober-Maret 2019, hh. 67-76

\section{b. Faktor lingkungan}

Hasil penelitian menunjukkan bahwa lingkungan juga merupakan faktor paling dominan terhambatnya masyarakat dalam mengimplementasikan sikap peduli sosial. Lingkungan Dusun Bumi Permai ini dapat dilihat sebagai lingkungan yang cukup sepi, hanya sedikit kegiatan sosialisasi yang dilakukan oleh warga. Masyarakat tersebut cenderung menghabiskan waktu untuk bekerja dan ketika pulang akan berdiam di dalam rumah. Sehingga hampir sedikit pergaulan yang berada di dusun tersebut dan dapat dikatakan bahwa masyarakat sedikit acuh dengan kondisi masyarakat lain dalam hal bersosialisasi.

\section{c. Faktor media elektronik}

Dampak negatif dari kecanggihan media elektronik yang diterima masyarakat Dusun Bumi Permai yaitu rasa ketergantungan terhadap media elektronik seperti tv dan handphone yang dapat membuat masyarakat tersebut menjadi malas dan lebih fokus terhadap dunia maya sehingga menimbulkan sikap acuh terhadap orang lain.

\section{d. Faktor waktu dan kesempatan}

Bersarkan komposisi masyarakat Dusun Bumi Permai yang memiliki latar belakang sebagai pekerja, maka waktu dan kesempatan yang dimiliki oleh warga-warga tersebut untuk mengimplementasikan sikap peduli sosial sangat sedikit. Banyak warga yang tidak memiliki waktu luang untuk mengikuti kegiatan-kegiatan yang diadakan. Sehingga untuk membantu berupa tenaga, hanya sedikit warga yang beredia. Namun warga yang tidak memiliki waktu tersebut menutupnya dengan bantuan dana atau materi.

\section{PENUTUP}

\section{Simpulan}

1. Bentuk sikap peduli sosial pada masyarakat dusun Bumi Permai, Labuapi, Lombok Barat, sebagai berikut: a) Tolong Menolong; b) Toleransi; c) Kerjasama; d) Empati

2. Implementasi sikap peduli sosial pada masyarakat dusun Bumi Permai, Labuapi, Lombok Barat

a. Tolong Menolong, terdiri dari:

1) Menolong tetangga yang sakit;

2) Menjadi relawan;

3) Membagikan makanan untuk buka puasa

b. Toleransi, antara lain:

1) Tidak mengganggu ibadah agama lain;

2) Komunikasi menggunakan bahasa nasional;

3) Ikut merayakan hari raya agama Islam; 
4) Menghargai perbedaan pendapat;

5) Menghargai perbedaan kepentingan

c. Kerjasama, antara lain:a) Gotong royong; b) Pembentukan dan pembubaran panitia acara.

d. Empati

Faktor penghambat dalam menerapkan sikap peduli sosial pada masyarakat di Dusun Bumi Permai, Kecamatan Labuapi, Kabupaten Lombok Barat, terdiri dari: Faktor Intern dan faktor ekstern. Faktor intern adalah kurangnya motivasi. Adapun faktor ekstern, antara lain: (1) Faktor keluarga; (2) Faktor lingkungan; (3) Faktor media elektronik; (4) Faktor waktu dan kesempatan.

\section{Saran}

1. Seluruh warga di Dusun Bumi Permai dapat mempertahankan dan meningkatkan sikap peduli sosial antar sesama.

2. Masyarakat lebih aktif berpartisipasi dalam berbagai acara yang diadakan di dusun

3. Masyarakat dapat mengubah sudut pandang dengan cara melihat perbedaan sebagai keberagaman yang justru memperkuat bangsa bukan melemahkan.

4. Masyarakat dapat mengembangkan sifat kekeluargaan, menguatkan jiwa gotong-royong serta mengutamakan musyawarah adalah cara terbaik memperkokoh persatuan dan kesatuan.

5. Masyarakat dapat menyadari bahwa persatuan dan kesatuan adalah syarat mutlak yang diperlukan sebuah Negara untuk mewujudkan cita-cita bersama yakni kehidupan yang sejahtera, adil dan makmur melalui implementasi sikap peduli sosial.

6. Kepala Dusun dan setiap ketua RT lebih intens dan fokus memantau kegiatan-kegiatan warga yang berhubungan dengan peduli sosial.

7. Kepala Dusun dan ketua RT dapat menjadi agen penggerak dan agen perubahan masyarakat. Bisa dilakukan dengan mengadakan kegiatan-kegiatan yang melibatkan masyarakat aktif untuk bergerak dibilang sosial dan peduli terhadap sesama.

8. Kepala Dusun dan Ketua RT membuat program-program kegiatan rutin bagi warga masyarakat agar tercipta aktivitas sosial pada masyarakat.

\section{UCAPAN TERIMA KASIH}

Ucapan terima kasih disampaikan kepada Jurusan Ilmu Pengetahuan Sosial FKIP UniversitasMataram dan Dewan Redaksi Juridiksiam yang menfasilitasi dalam penelitian danpublikasi hasil kajian ini. 
Vol. 6 No. 1, Oktober-Maret 2019, hh. 67-76

\section{DAFTAR RUJUKAN}

Abdurrahman, Muslan. 2009. Sosiologi dan Metode Penelitian Hukum. Malang: UMM Press.

Arikunto, Suharsimi. 2002. Metodologi Penelitian. Jakarta: PT. Rineka Cipta.

Bungin, Burhan H. M. 2007. Penelitian Kualitatif. Jakarta: Kencana Prenama Media Group.

Miles. B Matthew dan Huberman, A Michael, 1992. Analisis Data Kualitatif. Jakarta: Universitas IndonesiaPress.

Paramita, Prajna. 2014. Implementasi Karakter Kepedulian Sosial Pada Masyarakat Lereng Merapi (Studi Kasus Pada Komunitas Lereng Merapi di Desa Jrakah Kecamatan Selo Kabupaten Boyolali).Surakarta. Universitas Muhammadiyah Surakarta

Qoimatunnisa. 2017. Implementasi Ekstrakurikuler Pramuka Dalam Membentuk Karakter Mandiri dan Peduli Sosial Siswa (Studi Deskripstif Kualitatif di SMPN Se-Kecamatan Pringgarata Lombok Tengah. Skripsi tidak diterbitkan. Mataram: Program Sarjana Universitas Mataram. 